\title{
Smaller Benthonic Foraminifera from the Gahodleh Shales (Late Jurassic) of Somalia, and their Stratigraphic Significance
}

\author{
ROBERT WYNN JONES \\ BP Exploration (Frontier \& International), \\ 5 Long Walk, Stockley Business Park, Uxbridge, \\ Middlesex, UBIl lBP, UK.
}

\begin{abstract}
The smaller benthonic foraminifera identified by MacFadyen (1935) from the Gahodleh Shales of the former British Somaliland are reviewed, and several species are reidentified. The stratigraphic implications are discussed. J. Micropalaeontol., 12 (2): 175-180, December 1993.
\end{abstract}

\section{INTRODUCTION}

MacFadyen (1935) described twenty-four species of smaller benthonic foraminifera from Beds Ø214 and Ø215 of the Gahodleh Shales (MacFadyen, 1933) in the section exposed at Bihendula (Daghani) in the former British Somaliland (now part of the Somali Republic (Somalia)) (Figs. 1-2). He found the overlying Daghani Shales (MacFadyen, 1933) to be barren of foraminifera. Macfadyen (1935) identified the foraminifera from the Gahodleh Shales as Trochammina of. nitida Brady (Bed Ø215, 1 specimen), Haplophragmium agglutinans (d'Orbigny) (Bed Ø214, 2 specimens), H. pictonicum Berthelin (Bed Ø214, 2 specimens), Lagena streitbergensis Gümbel (Bed $\varnothing 215,1$ specimen), Nodosaria vetustissima (d'Orbigny) (Bed Ø215, 4 specimens), N. soluta (Reuss) (Bed Ø214, 2 specimens; Bed Ø215, 5 specimens), Frondicularia laevissima Terquem (Bed Ø215, 1 specimen), Triplasia somaliensis sp. nov. (Bed Ø215, 1 specimen), Vaginulina harpa Roemer (Bed Ø214, 2 specimens; Bed $Ø 215,1$ specimen), $V$. aff. flabellata (Gumbel) (Bed Ø215, 1 specimen), Cristellaria munsteri (Roemer) (Beds $\varnothing 214$ and 215, common), C. gibba d'Orbigny (Beds Ø214 and 215, fairly common (18 specimens altogether)), C. prima d'Orbigny (Bed Ø215, 6 specimens), C. quenstedti Gümbel (Bed Ø215, 15 specimens), C. megastoma Zwingli \& Kübler (Bed Ø215, 4 specimens), C. carinato-costata Deecke (Bed Ø214, 2 specimens), C. protracta Bornemann (Bed Ø215, 3 specimens), C. tricarinella Reuss (Bed Ø214, 1 specimen), C. triquetra Gümbel (Bed Ø215, 2 specimens), Epistomina elegans (d'Orbigny) (Bed Ø215, abundant (86 specimens)), E. reticulata (Reuss) (Bed Ø214, frequent (24 specimens)), E. ornata (Roemer) (Bed Ø214, frequent (23 specimens); Bed Ø215 rare (6 specimens)), Bullopora rostrata Quenstedt (Bed Ø215, 3 specimens (adherent to shell fragments)) and Nonion cf. fraasanus (Gümbel) (Bed Ø215, 1 specimen)). MacFadyen's specimens are housed in three cavity slides (640-642) in the Sedgwick Museum, Cambridge, where they have been examined by the author. His figures (drawings by Miss E.T. Talbot) are reproduced on Pl. 1. Curatorial details are included on the accompanying plate explanation. By reference to the modern literature, I have attempted to resolve the nomenclatorial problems alluded to by MacFadyen ("the determination of Jurassic foraminifera
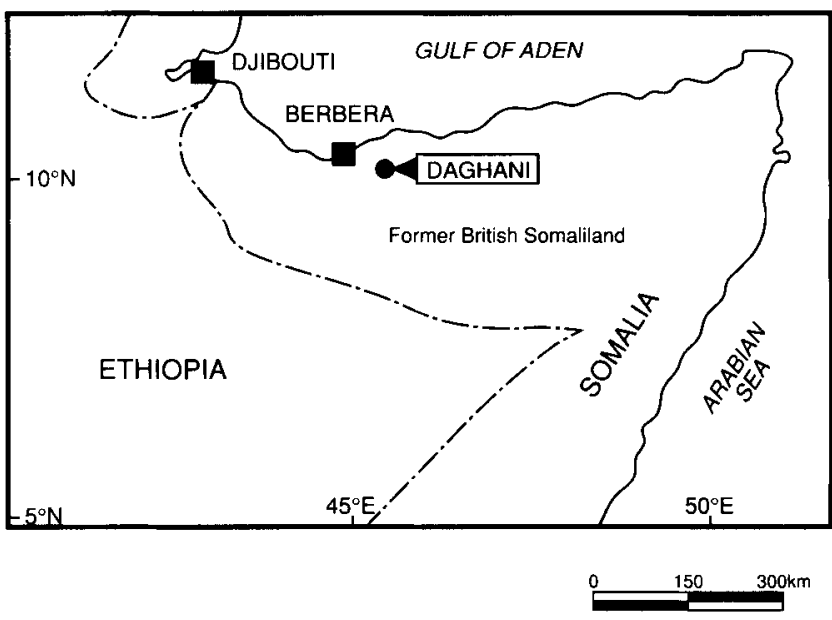

Fig. 1 Location Map. During the Late Jurassic, much of the area shown on this map lay under a shallow sea, although deeper conditions prevailed in the Berbera Trough (immediately west of Bihendula (Daghani)) and in the sub-basin south of the El Hamurre Fault (running W-E at about $7 \mathrm{~N}$ on the other side of the Arabo-Somali Massif) (see, for instance, Arkell, 1956; Bosellini, 1992).

presents special difficulties at the present time, particularly as regards nomenclature ... due in large part to the confusion arising from the older literature ..."), and have reidentified several species, as indicated on Table 1.

\section{AGE AND PALAEOENVIRONMENTAL INTERPRETA-} TION OF THE GAHODLEH SHALES

The Age of the Gahodleh Shales has been variously interpreted in the Somalian literature as "Argovian" (MacFadyen, 1935) or "Argovian" to Early Kimmeridgian (Furon, 1956; Barnes, 1976), apparently essentially on some somewhat inconclusive cephalopod evidence provided by Spath (1935) (the presence of indeterminate perispherinctid ammonites in Bed $\varnothing 214$ of the Bihendula (Daghani) section, and of the belemnite Belemnopsis tanganensis (the precise age significance of which is doubtful) in both Beds Ø214 and 215). Although in the Somalian literature the stage name 




Fig. 2 The Measured Section at Bihendula (Daghani) (from MacFadyen, 1933). Lat. $1090^{\prime}$ N., Long. $4510^{\prime} \mathrm{E}$. Vertical scale 1: 10 000. Measurements in metres. $\varnothing 190$ to $\varnothing 228$ indicate samples collected by MacFadyen. The Gahodleh and Daghani Shales were analysed for foraminifera. The Daghani Shales proved unproductive.
"Argovian" has been used more or less consistently to denote Oxfordian/Kimmeridgian, this is neither appropriate nor advisable. The Argovian (stratotypified at Argovie in the Swiss Alps) is equivalent to the Late Oxfordian (see, for instance, Arkell (1956) and Dreyfuss (1956)), but the term has been used loosely to denote "Middle Jurassic" to "Corallian" (Harland et al., 1982). As indicated on Table 3, I have interpreted the age of the Gahodleh Shales (as represented by Beds Ø214 and Ø215) as Late Oxfordian. This age is in accord with that assigned by Arkell (1956) on the basis of stratigraphic relationships. It is essentially based on the occurrence of the smaller benthonic foraminifer Epistomina reticulata sensu Shipp, 1989 (non Rotalia reticulata Reuss 1863), whose stratigraphic range is constrained by ammonite control (Middle to Late Oxfordian, Tenuiserratum to Regulare Zones), (See Table 2.) A tentative correlation can be made with the $147 \mathrm{Ma}$ maximum flooding surface of Haq et al. (1987) (see also Bosellini, 1992).

\section{Palaeoenvironmental Interpretation}

With regard to the palaeo-environmental interpretation of the Gahodleh Shales, a "shelfal" setting is suggested both by regional palaeogeographic reconstructions (Azzaroli \& Fois, 1964; Bosellini, 1992) and by the local lithofacies (argillaceous, non-calcareous). The benthonic foraminiferal assemblages are entirely consistent with a shelfal interpretation. Such species as Dentalina pseudocommunis and Lenticulina muensteri s. l. were typically "mid" shelfal in the Jurassic, according to the palaeobathymetric range chart constructed by Johnson (1976) for the Lias of the Mochras Borehole, offshore U.K. Significantly, both "inner" shelf (Citharina spp. ) and "outer" shelf (Reinholdella spp.) species are conspicuous by their absence.

\section{Explanation of Plate 1}

Fig. 1 Ammobaculites sp. Bed Ø214. x 21. Sedgwick Museum Slide 642, Square 22. Fig. 2 Haplophragmium ex gr. inconstans Bartenstein \& Brandt. Bed Ø214. x21. Sedgwick Museum Slide 642, Square 23. Fig. 3 Lagena streitbergensis Gümbel. Bed Ø215. x46. Sedgwick Museum Slide 642, Square 20. Fig. 4 Dentalina pseudocommunis Franke. Bed Ø215. x46. Sedgwick Museum Slide 642, Square 2. Fig. 5 Dentalina sp. Bed Ø215. x46. Sedgwick Museum Slide 642, Square 1. Fig. 6 Frondicularia laevissima Terquem. Bed Ø215. x46. Sedgwick Museum Slide 642, Square 6. Fig. 7 Triplasia somaliensis MacFadyen. Bed Ø215. x46. Sedgwick Museum Slide 642, Square 21. Figs. 8-9 Citharina serratocostata (Gümbel). Bed Ø215. x46. Sedgwick Museum Slide 642, Squares 3 (Fig. 8) and 4 (Fig. 9). Figs. 10-11 Lenticulina mutensteri (Roemer) s.1. Bed Ø214. Fig. $10 \times 37$; Fig. 11 ×46. Sedgwick Museum Slide 642, Squares 12 (Figure 10) and 15 (Fig. 11 ). Fig. 12 Lenticulina prima (d’Orbigny). Bed Ø215. x46. Sedgwick Museum Slide 642, Square 8. Fig. 13 Lenticulina quenstedti (Gümbel). Bed Ø214. x46. Sedgwick Museum Slide 642, Square 10. Fig. 14 Lenticulina ectypa (Loeblich \& Tappan). Bed Ø215. x46. Sedgwick Museum Slide 642, Square 9. Figs. 15-16 Planularia carinatocostata (Deecke). Bed O214. x46. Sedgwick Museum Slide 642, Square 14. Fig. 17 Astacolus major (Bornemann). Bed Ø215. x46. Sedgwick Museum Slide 642, Square 7. Fig. 18 Planularia tricarinella (Reuss). Bed $\varnothing 214 . \times 46$. Sedgwick Museum Slide 642, Square 11. Fig. 19 Saracenaria triquetra (Gümbel). Bed Ø215. x46. Sedgwick Museum Slide 642, Square 16. Fig. 20 Epistomina parastelligera (Hofker). Bed Ø215. X46. Sedgwick Museum Slide 642, Square 17. Fig. 21 Epistomina reticulata sensu Shipp. Bed Ø214. X46. Sedgwick Museum Slide 642, Square 18. Fig. 22 Epistomina mosquensis Uhlig. Bed Ø1214. x46. Sedgwick Museum Slide 642, Square 19. Figs. 23-24 Bullopora rostrata Quenstedt. Bed p215. x46. Sedgwick Museum Slide 642, Square 24. Fig. 25 ?Lenticulina sp. Bed Ø215. x46. Sedgwick Museum Slide 642, Square 5. 


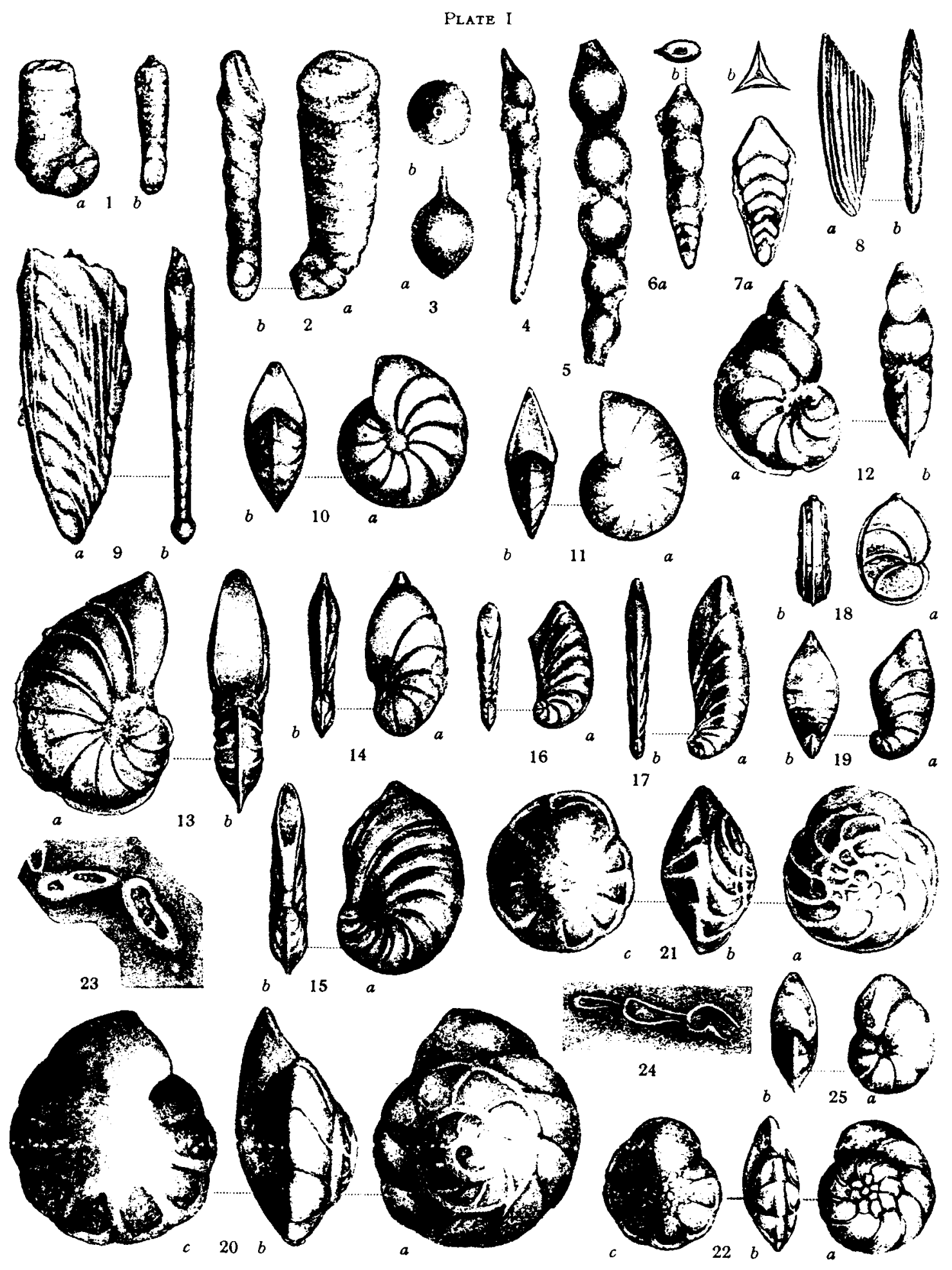




\begin{tabular}{|l|c|}
\hline \multicolumn{2}{|c|}{$\begin{array}{c}\text { Comparative Terminology of Smaller Benthonic } \\
\text { Foraminifera from the Gahodleh Shales }\end{array}$} \\
\hline \multicolumn{1}{|c|}{ MacFadyen (1935) } & This Paper \\
\hline Haplophragmium agglutinans & Ammobaculites sp. (*) \\
\hline Haplophragmium pictonicum & Haplophragmium ex gr. inconstans \\
\hline Lagena streitbergensis & No change \\
\hline Nodosaria vetustissima & Dentalina pseudocommunis \\
\hline Nodosaria soluta & Dentalina sp \\
\hline Frondicularia laevissima & No change \\
\hline Triplasia somaliensis & No change \\
\hline Vaginulina harpa & Citharina serratocostata \\
\hline Vaginulina aff flabellata & Citharina serratocostata \\
\hline Cristellaria munsteri & Lenticulina muensteri s.l. \\
\hline Cristellaria gibba & Lenticulina muensteri s.l. \\
\hline Cristellaria prima & Lenticulina prima \\
\hline Cristellaria quenstedti & Lenticulina quenstedti \\
\hline Cristellaria megastoma & Lenticulina ectypa \\
\hline Cristellaria carinato-costata & Planularia carinatocostata \\
\hline Cristellaria protracta & Astacolas major \\
\hline Cristellaria tricarinella & Planularia tricarinella \\
\hline Cristellaria triquetra & Saraceneria triquetra \\
\hline Epistomina elegans & Epistomina parastelligera \\
\hline Epistomina reticulata & No change \\
\hline Epistomina ornata & Epistomina mosquensis \\
\hline Bullopora rostrata & No change \\
\hline Nonion cf fraasanus & Lenticulina sp. \\
\hline & \\
\hline
\end{tabular}

\section{REGIONAL CORRELATION (SOMALIA TO THE ARABIAN PENINSULA)}

A lithostratigraphic correlation can be made between the Middle to Late Jurassic sections of Somalia and the Arabian Peninsula (which were at that time, prior to the rifting in the Gulf of Aden, contiguous). This correlation (Table 3) indicates that the Madbi Formation of the Yemen is partly equivalent to the Gahodleh Shales of Somalia, and is therefore at least in part of Oxfordian age. This in turn provides independent constraint on the ages of the overlying surface and subsurface formations of the Yemen, which was formerly lacking (ages being based on larger benthonic foraminiferal and palynomorph datums generally only loosely calibrated against standard ammonite zonations). This is important in that certain of the subsurface formations constitute important petroleum reservoirs in fields in the Marib Jawf Graben (see, for instance, Maycock (1987), Huurdeman et al. (1989) and Ali Tahera et al. (1992)).

\section{CONCLUSIONS}

Reidentifications of some of the smaller benthonic foraminifera identified by MacFadyen (1935) from the Gahodleh Shales of Somalia enable a refinement of the stratigraphic interpretation of the formation. An Oxfordian age is assigned. An Oxfordian age is also assigned to the presumed equivalent Madbi Formation, which underlies petroliferous formations in the subsurface of the Marib Jawf Grabenin the Yemen.

Table 1 Comparative Terminology of Late Jurassic Smaller Foraminifera from Spirolina agglutinans d'Orbigny, 1846).

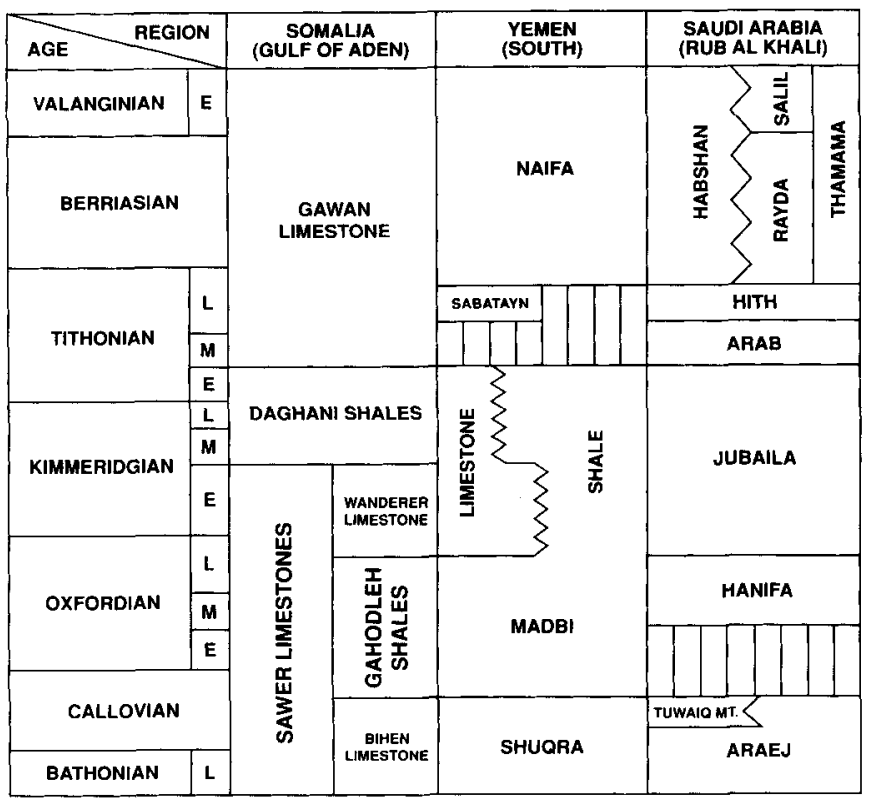

\section{ACKNOWLEDGEMENTS}

I wish to thank Khalid Al-Thour of the University of Birmingham, to Drs. Mike Howarth and Noel Morris of the British Museum (Natural History), and to Ms. Mairead Rutherford of BP for their comments on the stratigraphic succession in the Arabian Peninsula and its correlation with the Horn of Africa. I also wish to thank Mr. M. Dorling of the Sedgwick Museum, Cambridge for showing me around the MacFadyen collection on my visit to Cambridge, and Mr. R. Symonds of the University Museum of Zoology, Cambridge, for putting me in touch with Mr. Dorling. BP provided drafting facilities.

\section{Manuscript received August 1992 Manuscript accepted June 1993}

\section{REFERENTCES}

Table 3 Late Jurassic to Early Cretaceous Stratigraphic Correlation, Somalia to the Arabian Peninsula. Compiled from various sources, chief]y MacFadyen (1933), Beydoun (1964, 1970, 1988, 1991), Abbate et al. (1974), Barnes (1976), Ali Tahera et al. (1990), Bott (1992) and unpublished sources. Lithostratigraphic nomenclature follows the BP in-house usage. Madbi Limestone probably equivalent to lower ("platy") Naifa Formation of authors. 


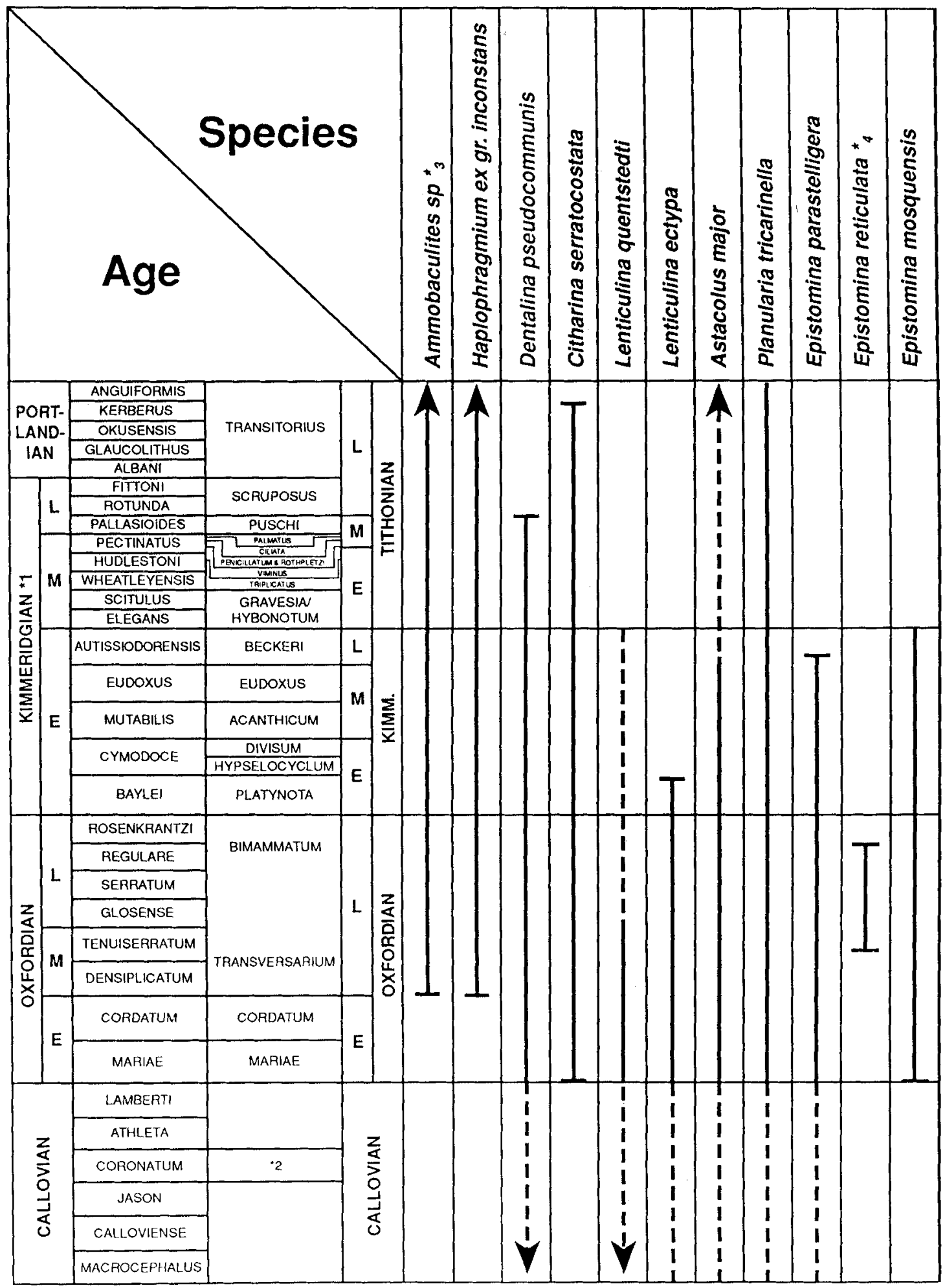

Table 2 Stratigraphic Ranges of Selected Smaller Benthonic Foraminifera from the Gahodleh Shale. Compiled from various sources, chiefly Gradstein et al. (1989) (Central Asia) and Shipp (1989) and references therein (Europe). Ammonite zonations from Haq et al. (1987ab) (Boreal) and Arkell (1956), Verma \& Westermann (1984) and Enay et al. (1987) (Tethyan). Bold line indicates ammonite control, dashed line indicates no ammonite control. Shading indicates inferred age-range of sampled part of Gahodleh Shale. ${ }^{*} 1=$ sensu Anglico; ${ }^{*} 2=$ Erymnoceras, Pachyermynoceras, "Prorsiceras" gr. hatirae, Grossouvria and Proplanulitidae; ${ }^{*} 3=$ Ammobaculites agglutinans sensu Shipp, 1989 ; $* 4=$ sensu Shipp, 1989. 
Abbate, E., Ficcarelli, G., Pirini Radrizzani, C., Salvietti, A., Torre, A. \& Turi, A., 1974. Jurassic Sequence from the Somali Coast of the Gulf of Aden. Riv. ital. Paleont. Stratigr., Milano, 80(3), 409478.

Ali Tahera, A., Sturgess, M., Maycock, I., Mitchell, G., Prelat, A., Numi, R. \& Petricola, M., 1992. Looking for Yemen's Hidden Treasure. Middle East Well Evaluation Rev., 12, 12-29.

Arkell, W.J., 1956. The Jurassic Geology of the World. Edinburgh (Oliver \& Boyd).

Azzaroli, A. \& Fois, V., 1964. Geological Outlines of the Northern End of the Horn of Africa. Proc. Twenty-Second Int. geol. Congr., 4, 293-314.

Barnes, S.U., 1976. Geology and Oil Prospects of Somalia, East Africa. Amer. Assoc. Petrol. Geol. Bull., Tulsa, Oklahoma, 60(3), 389-413.

Beydoun, Z.R., 1964. The Stratigraphy and Structure of the Eastern Aden Protectorate. London (H.M.S.O. (Overseas Geology and Mineral Resources Supplement Series)).

Beydoun, Z.R., 1970. Southern Arabia and Northern Somalia: Comparative Geology. Phil. Trans. R. Soc., London, A267, 267292.

Beydoun, Z.R., 1988. The Middle East: Regional Geology and Petroleum Resources. Beaconsfield, Bucks. (Scientific Press).

Beydoun, Z.R., 1991. Arabian Plate Hydrocarbon Geology and Potential - a Plate Tectonic Approach. Tulsa, Oklahoma (American Association of Petroleum Geologists).

Bosellini, A., 1992. The Continental Margins of Somalia: Structural Evolution and Sequence Stratigraphy. In Watkins, J.S., Feng Zhiqiang \& McMillen, K.J. (Eds.), Geology and Geophysics of Continental Margins, 185-206. Tulsa, Oklahoma (American Association of Petroleum Geologists)

Bott, W.F., Smith, B.A., Oakes, G., Sikander, A.H. \& Ibrahim, A.I., 1992. The Tectonic Framework and Regional Hydrocarbon Prospectivity of the Gulf of Aden. J. Petrol. Geol., Beaconsfield, 15(2), 211-243.

Dreyfuss, M. (Dir.), 1956. Europe: France, Belgique, Pays-Bas, Luxembourg: Jurassique s. str. Lexique Strat. Int., Paris, $\mathbf{I}(4 \mathrm{aV})$.

Enay, R. (Co-Ord.), 1987. Le Jurassique d'Arabie Saoudite Centrale. Geobios, Mem. Spec., Lyon, 9.

Furon, R. (Dir.), 1956. Afrique: British Somaliland, Somalie Francaise, Somalia Italiana, Ethiopie-Erythree. Lexique Strat. Int, Paris, IV(5)

Gradstein, F.M., Gibling, M.R., Jansa, L.F., Kaminski, M.A., Ogg, J.G., Sarti, M., Thurow, J.W., von Rad, U. \& Westermann, G.E.G., 1989. Mezozoic Stratigraphy of Thakkhola, Central Nepal. Halifax, Nova Scotia (Centre for Marine Geology,
Dalhousie University).

Haq, B.U., Hardenbol, J. \& Vail, P.R., 1987a. Chronology of Fluctuating Sea-Levels Since the Triassic (250 Million Years Ago to the Present). Science, New York, 235, 1156-1167.

Haq, B.U., Hardennbol, J. \& Vail, P.R., 1987b. New Chronostratigraphic Basis of Cenozoic and Mesozoic SeaLevel Cycles. Spec. Publs. Cushman Found. foramin. Res. Washington, D.C., 24, 7-14.

Harland, W.B., Cox, A.V., Llewellyn, P.G., Pickton, C.A.G., Smith, A.G. \& Walters, R., 1982. A Geologic Time Scale. Cambridge (University Press)

Huurdeman, A.J.M., Breunese, J.N., Al-Asbahi, A., Lutgert, J.E. \& Floris, F.L.T., 1989. Assessment of Halite-Cemented Reservoir Zones with a Combined Geological/Engineering Approach: a Case Study. SPE, Houston, Texas, 19603.

Johnson, B., 1976. Ecological Ranges of Selected Toarcian and Domerian (Jurassic) Foraminiferal Species from Wales. Marit. Sediments spec. Publs., Halifax, Nova Scotia, IB, 545-556.

MacFadyen, W.A., 1933. The Geology and Palaeontology of British Somaliland, Part I: The Geology of British Somaliland. Government of Somaliland Protectorate.

MacFadyen, W.A., 1935. Jurassic Foraminifera. In MacFadyen, W.A., Dighton Thomas, H., Currie, E.D., Hawkins, H.L., Bather, F.A., Muir-Wood, H.M., Cox, L.R. \& Spath, L.F. (Eds.), The Geology and Palaeontology of British Somaliland, Part II: The Mesozoic Stratigraphy of British Somaliland, 7-20. Government of Somaliland Protectorate.

Maycock, I.D., 1987. Exploration and Development in Marib/ Al Jawf Basin, Yemen Arab Republic. Houston geol. Soc. Bull., 31, 8.

Shipp, D.J., 1989. The Oxfordian to Portlandian (Upper Jurassic). In Jenkins, D.G. \& Murray, J.W. (Eds.), Stratigraphical Atlas of Fossil Foraminifera, 237-272. Chichester (Ellis Horwood Ltd.). Spath, L.F., 1935. Jurassic and Cretaceous Cephalopoda. In MacFadyen, W.A., Dighton Thomas, H., Currie, E.D., Hawkins, H.L., Bather, F.A., Muir-Wood, H.M., Cox, L.R. \& Spath, L.F. (Eds.), The Geology and Palaeontology of British Somaliland, Part II: The Mesozoic Stratigraphy of British Somaliland, 205-228. Government of Somaliland Protectorate.

Verma, H.M. \& Westermann, G.E.G., 1984. The Ammonoid Fauna of the Kimmeridgian-Tithonian Boundary Beds of Mombasa, Kenya. Contr. Life Sci. Div. R. Ont. Mus., Toronto, 135. 